\title{
Formaldehyde and Glutaraldehyde Inactivation of Bacterial Tier 1 Select Agents in Tissues
}

\author{
Jennifer Chua, ${ }^{1}$ Joel A. Bozue, ${ }^{1}$ Christopher P. Klimko, Jennifer L. Shoe, Sara I. Ruiz, \\ Christopher L. Jensen, Steven A. Tobery, Jared M. Crumpler, Donald J. Chabot, \\ Avery V. Quirk, Melissa Hunter, David E. Harbourt, Arthur M. Friedlander, Christopher K. Cote
}

For safety, designated Select Agents in tissues must be inactivated and viability tested before the tissue undergoes further processing and analysis. In response to the shipping of samples of "inactivated" Bacillus anthracis that inadvertently contained live spores to nonregulated entities and partners worldwide, the Federal Register now mandates in-house validation of inactivation procedures and standardization of viability testing to detect live organisms in samples containing Select Agents that have undergone an inactivation process. We tested and validated formaldehyde and glutaraldehyde inactivation procedures for animal tissues infected with virulent B. anthracis, Burkholderia pseudomallei, Francisella tularensis, and Yersinia pestis. We confirmed that our fixation procedures for tissues containing these Tier 1 Select Agents resulted in complete inactivation and that our validated viability testing methods do not interfere with detection of live organisms. Institutions may use this work as a guide to develop and conduct their own testing to comply with the policy.

$\mathrm{D}$ espite being a disease of antiquity, anthrax remains a public health concern and is considered a reemerging threat in developed countries, in part because of bioterrorism (1). Threats of bioterrorism and the ease of global travel have led nations to also be concerned about diseases such as tularemia, plague, and melioidosis (1). In addition, natural outbreaks and the global distribution and endemic nature of these bacteria continue to be subjects of public health and biodefense research.

In the United States, biological agents and toxins with the potential to pose a severe threat to public health and safety are overseen by the Federal Select Agents Program (https://www.selectagents.gov), a joint program of the Centers for Disease Control and Prevention/Division of Select Agents and Toxins and the US Department of Agriculture Animal and Plant Health Inspection Service/Agriculture

Author affiliation: United States Army Medical Research Institute of Infectious Diseases, Frederick, Maryland, USA

DOI: https://doi.org/10.3201/eid2505.180928
Select Agent Services. Agents that pose a particularly high risk to humans are classified as Tier 1 Select Agents; Bacillus anthracis is a Tier 1 Select Agent.

Work with Select Agents necessitates complete inactivation because these organisms can cause serious illness or death and could potentially endanger public health through accidental infection of laboratory workers. In 2015, virulent $B$. anthracis samples thought to be completely inactivated by irradiation were unwittingly sent to unregistered laboratories (2). These samples, containing spores produced to support research and development for detection and medical countermeasures, were sent to domestic and international entities not under the purview of the Federal Select Agent Program. Although the samples contained low numbers of live organisms and did not pose a serious risk, this event was a breach in a regulation intended to restrict access to the pathogen and safeguard public health. Investigations at the transgressing facility revealed that $B$. anthracis could be cultured from multiple $\gamma$-irradiated batches of spores (2). Another troubling aspect was the failure of viability tests, performed after irradiation, to detect viable organisms. Thus, the US Department of Defense developed a well-characterized and reproducible method for inactivating $B$. anthracis spores with irradiation (3). In addition, all validation of inactivation procedures and viability testing involving Tier 1 Select Agents at each institution is now mandated by federal regulation (4).

A common way to inactivate infectious agents in tissues before histologic analysis is formaldehyde fixation, coincidentally first characterized in 1893 with the fixation of $B$. anthracis-infected tissue (5). Glutaraldehyde, the use of which was described decades later in 1963 (6), is commonly used to inactivate samples for electron microscopy (EM) analysis. These related aldehydes cross-link primary amines and other reactive groups in proteins, fatty acids, and nucleic acids, thereby halting biochemical reactions and placing cellular structures in permanent stasis

${ }^{1}$ These authors contributed equally to this article. 
resembling structures found in living tissue $(5,7-9)$. Formaldehyde molecules are small and diffuse quickly but fix tissue slowly $(7,10)$. An attractive property of formaldehyde fixation is that it is partially reversible and some denatured antigens can be retrieved to be again recognized by antibodies (11). In contrast, the larger glutaraldehyde molecules fix tissues quickly and irreversibly but do not penetrate thick tissues well.

Despite a century of use, formaldehyde inactivation of tissues containing Select Agents has been described in few reports $(12,13)$. Frequently, studies test only a small fraction of tissue for complete inactivation (14), which carries a risk of concealing low numbers of viable organisms in the remaining sample. The process of fixation, and concurrently that of inactivation, is dependent on variables such as time, $\mathrm{pH}$, temperature, fixative concentration, and tissue size/ composition $(10,15-17)$. The desire to accelerate the fixation process for faster workflow $(15,17)$ increases the risk for incomplete inactivation. Because $B$. anthracis spores in particular are hardy (i.e., resistant to heat, radiation, and chemicals) $(1,18)$, their inactivation is more difficult.

The detection of viable organisms in partially inactivated tissues relies on the organisms' ability to proliferate when placed in rich growth media. However, fixative is probably retained internally in tissues, potentially interfering with growth during viability testing. The key function of a viability test is to detect viable organisms by encouraging the proliferation of any organisms, live or injured, that may have survived the inactivation procedure. Testing for viability requires the removal or neutralization of the inactivating agent that may interfere with growth. Removing or neutralizing chemical fixatives is particularly important because their presence might restrict organism proliferation at low, nonlethal concentrations. Similar to the time required for penetration into thick tissues (10), adequate time for washing must be provided to allow for outward diffusion. As an alternative, fixative in tissue, including any inhibitory components from the tissue itself, can be diluted in a large volume of medium used for the viability test. Tissue disaggregation or homogenization also exposes potentially live organisms deep within tissues to nutrient-rich medium, allowing growth.

We tested and validated inactivation procedures that used formaldehyde with or without glutaraldehyde on lung, liver, spleen, and skin from infected animals destined for microscopic analyses. Our validation procedure is aligned with requirements set forth by the Centers for Disease Control and Prevention (CDC), under the US Health and Human Services, as mandated in the Federal Register (42 CFR §73) (4). We confirmed that our inactivation procedures for tissue fixation resulted in complete inactivation and validated neutralization procedures for viability testing. This work specifically focused on the agents that cause anthrax, melioidosis, tularemia, and plague but could be applicable to others. Because we demonstrated fixation of highly resistant spores, this work could also be applied to unknown or undetermined etiologic agents with uncharacterized properties that cause other emerging infectious diseases.

\section{Materials and Methods}

\section{Bacterial Strains and Culture}

We placed spores of $B$. anthracis Ames (pXO1+/pXO2+), Sterne, and ANR (pXO1+/pXO2-) in Leighton and Doi broth (19) or on NBY agar plates (20) and purified them with Omnipaque (GE Healthcare, https://www.gehealthcare.com) as previously described (21). All spores were heated for $30 \mathrm{~min}$ at $65^{\circ} \mathrm{C}$ before animal infection. Bacilli were grown in brain heart infusion broth (Difco; Becton, Dickinson and Company, http://www.bd.com), on tryptic soy agar, or on sheep blood agar (SBA) plates (Remel ThermoFisher Scientific, https://www.thermofisher.com) at $37^{\circ} \mathrm{C}$. Burkholderia pseudomallei $1026 \mathrm{~b}$ and B. pseudomallei 82 (purine auxotroph) were grown in Luria Bertani (Lennox) broth (Difco) with 4\% glycerol (Sigma Aldrich, https://www.sigmaaldrich.com) (22) or on SBA plates. Francisella tularensis Schu S4 and live vaccine strain were grown in either brain heart infusion broth with $1 \%$ IsoVitaleX (Becton, Dickinson and Company) or on chocolate agar plates (Remel) at $37^{\circ} \mathrm{C}$. Yersina pestis $\mathrm{CO} 92$ and $Y$. pestis Pgm-/pPst- were grown in heart infusion broth with $0.2 \%$ xylose (Sigma Aldrich) or on SBA plates at $28^{\circ} \mathrm{C}$. All bacterial strains were from the collection at the US Army Medical Research Institute of Infectious Diseases (Frederick, MD, USA).

\section{Chemical Fixatives}

The standard fixative for tissue destined for light microscopy analyses is $4 \%$ formaldehyde, which is used interchangeably with $10 \%$ neutral buffered formalin, $10 \%$ buffered formalin phosphate (Fisher Chemical, https://www. fishersci.com), or 4\% paraformaldehyde. Immediately before its use, we used phosphate-buffered saline (PBS), $\mathrm{pH}$ 7.4 , to dilute $16 \%$ paraformaldehyde (Electron Microscopy Sciences, https://www.emsdiasum.com) to $4 \%$ paraformaldehyde. We fixed tissues destined for EM with 4\% paraformaldehyde and 1\% glutaraldehyde (Electron Microscopy Sciences) in $0.1 \mathrm{M}$ sodium cacodylate (Sigma Aldrich) buffer (14). This combination is referred to as EM fixative.

\section{Fixative Removal from Tissue and Formaldehyde Sensitivity Assays}

Because of their size and the amount of tissue that can be obtained, we used guinea pigs for these assays. We harvested spleen, liver, outer ear pinna, and skin from euthanized guinea pigs. To enable effective penetration of fixative, 
Table 1. Formaldehyde fixation of Bacillus anthracis Ames-infected skin tissue from guinea pigs in study of inactivation of bacterial Tier 1 Select Agents*

\begin{tabular}{|c|c|c|c|c|c|}
\hline $\begin{array}{l}\text { Fixation time, d, } \\
\text { no. samples }\end{array}$ & $\begin{array}{c}\text { Maximum tissue } \\
\text { weight, g }\end{array}$ & Maximum tissue size, $\mathrm{mm}$ & $\begin{array}{l}\text { Total CFU } \\
\text { recovered/g }\end{array}$ & $\begin{array}{c}\text { Sample } \\
\text { inactivationt }\end{array}$ & $\begin{array}{c}\text { Positive control } \\
\text { inactivationt }\end{array}$ \\
\hline 7,3 & 2.04 & $20 \times 30 \times 3$ & $6.15 \times 10^{7}$ & $+/+\ddagger$ & $+/+$ \\
\hline 14,3 & 1.94 & $23 \times 28 \times 3$ & $5.41 \times 10^{7}$ & $-1-$ & $+/+$ \\
\hline 21,3 & 2.55 & $28 \times 28 \times 3$ & $4.86 \times 10^{7}$ & $-1-$ & $+/+$ \\
\hline
\end{tabular}

we excised tissues $\leq 10 \mathrm{~mm}$ in 1 dimension. Samples were incubated in fixative $(\geq 1: 10 \mathrm{wt} / \mathrm{vol})$ at ambient temperature for various times. To allow for outward diffusion of fixative, we soaked samples in PBS/water; ear and spleen required longer submersion to support bacterial growth. Tissues were cut into smaller pieces, ground with a homogenizer (Pro200; Pro Scientific, https://proscientific.com), and then transferred to broth $(\geq 1: 50 \mathrm{wt} / \mathrm{vol})$. In accordance with CDC policy on the neutralization method, we split the broth into 2 aliquots: 1 was inoculated with $5 \times 10^{3}$ Sterne spores and the other was left as is. The 7-day broth-to-plate viability test for $B$. anthracis was performed by culturing in broth ( $\geq 1: 10 \mathrm{wt} / \mathrm{vol})$ followed by solid medium $(\geq 100 \mu \mathrm{L})$, each incubated for 7 days at $37^{\circ} \mathrm{C}(23)$. To detect growth in broth, we read optical densities at $620 \mathrm{~nm}$ by using a spectrophotometer (Genesys 20, ThermoFisher Scientific).

To test genus-specific sensitivity to formaldehyde, we used B. pseudomallei 1026b, B. anthracis Sterne, B. pseudomallei $82, F$. tularensis live vaccine strain, and $Y$. pestis Pgm-/pPst-. Strains were incubated in broth with formaldehyde (10\% neutral buffered formalin diluted 10-fold from $1: 10$ to $1: 10,000)$ and shaken for up to 5 days. The starting inoculum was plated for CFU.

\section{Animal Challenges}

To limit the number of animals used, we repurposed Hartley guinea pig survivors (Table 1); repurposing was deemed appropriate because of the short duration of the study and because dissemination of bacteria into organs was not required. After administering an intramuscular injection of ketamine, acepromazine (both from Vedco, https://www. vedco.com), and xylazine (Akorn, Inc., http://www.akorn. com), we injected the guinea pigs intradermally at several demarcated locations with $2 \times 10^{8} \mathrm{~B}$. anthracis Ames spores. To maximize the number of ungerminated spores, we collected whole-skin samples at 2 hours after challenge.

For spleen, liver, and lung tissue collection, we used $\leq 4$ naive Strain 13 guinea pigs per Select Agent (Tables $2,3)$. To maximize spores in the lungs, we administered $B$. anthracis Ames spores to the guinea pigs by the inhalation route (24); to enable rapid dissemination to the spleen and liver, we also administered them by the intramuscular route

\begin{tabular}{|c|c|c|c|c|c|c|}
\hline Infectious agent, tissue type & $\begin{array}{l}\text { Maximum tissue } \\
\text { weight, } g\end{array}$ & $\begin{array}{l}\text { Maximum tissue } \\
\text { size, } \mathrm{mm}\end{array}$ & Maximum CFU/g & $\begin{array}{l}\text { Fixation } \\
\text { time, } d\end{array}$ & $\begin{array}{c}\text { Sample } \\
\text { inactivation }\end{array}$ & $\begin{array}{l}\text { Positive control } \\
\text { inactivation }\end{array}$ \\
\hline \multicolumn{7}{|c|}{ Bacillus anthracis Ames (inhalational and intramuscular), $\mathrm{n}=3$} \\
\hline Spleen & 1.04 & $20 \times 20 \times 6$ & $1.1 \times 10^{9}$ & 13 & $-1-\dagger$ & + \\
\hline Liver & 1.78 & $20 \times 10 \times 10$ & $9.8 \times 10^{7}$ & 13 & $-1-\dagger$ & + \\
\hline Lung & 1.14 & $20 \times 20 \times 10$ & $\begin{array}{l}2.1 \times 10^{8} ; 5.5 \times 10^{4} \\
\text { (heat resistant) }\end{array}$ & 13 & $-1-\dagger$ & + \\
\hline \multicolumn{7}{|c|}{ Burkholderia pseudomallei 1026b, $\mathrm{n}=4$} \\
\hline Spleen & 0.81 & $20 \times 15 \times 10$ & $7.5 \times 10^{8}$ & 13 & $-1-\ddagger$ & + \\
\hline Liver & 2.15 & $20 \times 15 \times 10$ & $1.4 \times 10^{7}$ & 13 & $-1-\ddagger$ & + \\
\hline Lung & 1.56 & $20 \times 15 \times 10$ & $4.0 \times 10^{7}$ & $17-18$ & $-1-\ddagger$ & + \\
\hline \multicolumn{7}{|c|}{ Francisella tularensis Schu $\mathrm{S} 4, \mathrm{n}=3$} \\
\hline Spleen & 1.50 & $15 \times 15 \times 10$ & $9.3 \times 10^{9}$ & 13 & $-1-\S$ & + \\
\hline Liver & 2.29 & $25 \times 13 \times 11$ & $9.5 \times 10^{7}$ & 13 & $-1-\pi$ & + \\
\hline Lung & 1.30 & $15 \times 13 \times 11$ & $4.3 \times 10^{8}$ & 13 & $-1-\pi$ & + \\
\hline \multicolumn{7}{|l|}{ Yersina pestis C092, $\mathrm{n}=3$} \\
\hline Spleen & 0.96 & $15 \times 10 \times 8$ & $1.4 \times 10^{10}$ & 13 & $-1-\delta$ & + \\
\hline Liver & 2.09 & $30 \times 15 \times 10$ & $1.1 \times 10^{9}$ & 13 & $-1-\pi$ & + \\
\hline Lung & 1.81 & $25 \times 20 \times 15$ & $7.0 \times 10^{8}$ & 13 & $-1-\pi$ & + \\
\hline \multicolumn{7}{|c|}{ 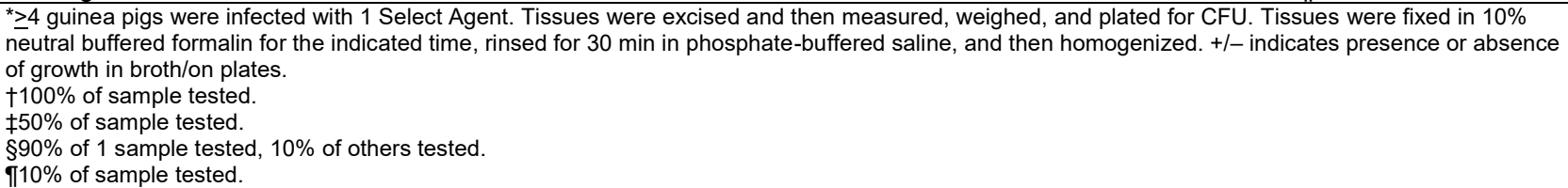 } \\
\hline
\end{tabular}


Table 3. Electron microscopy fixation of infected spleen, liver, and lung tissue from guinea pigs in study of inactivation of bacterial Tier 1 Select Agents*

\begin{tabular}{|c|c|c|c|c|c|c|}
\hline Infectious agent, tissue type & $\begin{array}{l}\text { Maximum tissue } \\
\text { weight, } g\end{array}$ & $\begin{array}{l}\text { Maximum tissue } \\
\text { size, } \mathrm{mm}\end{array}$ & Maximum CFU/g & $\begin{array}{l}\text { Fixation } \\
\text { time, } d \\
\end{array}$ & $\begin{array}{c}\text { Sample } \\
\text { inactivation }\end{array}$ & $\begin{array}{c}\text { Positive control } \\
\text { inactivation }\end{array}$ \\
\hline \multicolumn{7}{|c|}{ Bacillus anthracis Ames (inhalational and intramuscular), $\mathrm{n}=3$} \\
\hline Spleen & 0.15 & $10 \times 3 \times 2$ & $1.1 \times 10^{9}$ & 6 & $-1-\dagger$ & + \\
\hline Liver & 0.18 & $9 \times 5 \times 2$ & $9.8 \times 10^{7}$ & 6 & $-1-\dagger$ & + \\
\hline Lung & 0.08 & $10 \times 4 \times \times 2$ & $\begin{array}{c}2.1 \times 10^{8} ; 5.5 \times 10^{4} \\
(\text { heated })\end{array}$ & 6 & $-1-\dagger$ & + \\
\hline \multicolumn{7}{|c|}{ Burkholderia pseudomallei 1026b, $\mathrm{n}=4$} \\
\hline Spleen & 0.09 & $8 \times 4 \times 2$ & $7.5 \times 10^{8}$ & 7 & $-1-\ddagger$ & + \\
\hline Liver & 0.16 & $10 \times 6 \times 2$ & $1.4 \times 10^{7}$ & 7 & $-1-\ddagger$ & + \\
\hline Lung & 0.09 & $10 \times 4 \times 2$ & $4.0 \times 10^{7}$ & 7 & $-1-\ddagger$ & + \\
\hline \multicolumn{7}{|c|}{ Francisella tularensis Schu S4, $\mathrm{n}=3$} \\
\hline Spleen & 0.15 & $6 \times 6 \times 1$ & $9.3 \times 10^{9}$ & 6 & $-1-\S$ & + \\
\hline Liver & 0.15 & $11 \times 5 \times 1$ & $9.5 \times 10^{7}$ & 6 & $-1-\tilde{\pi}$ & + \\
\hline Lung & 0.08 & $7 \times 6 \times 1$ & $4.3 \times 10^{8}$ & 6 & $-1-\pi$ & + \\
\hline \multicolumn{7}{|l|}{ Yersina pestis CO92, $\mathrm{n}=3$} \\
\hline Spleen & 0.11 & $7 \times 5 \times 1$ & $1.4 \times 10^{10}$ & 6 or 8 & $-1-\S$ & + \\
\hline Liver & 0.07 & $7 \times 4 \times 1$ & $1.1 \times 10^{9}$ & 6 or 8 & $-1-\tilde{\pi}$ & + \\
\hline Lung & 0.07 & $7 \times 6 \times 1$ & $7.0 \times 10^{8}$ & 6 or 8 & $-1-\pi$ & + \\
\hline \multicolumn{7}{|c|}{ 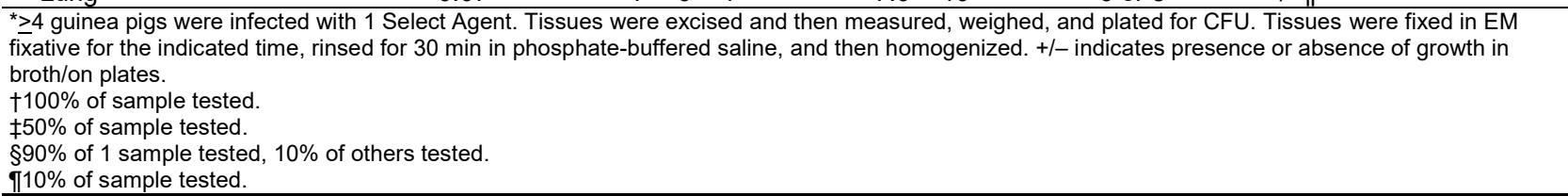 } \\
\hline
\end{tabular}

(25). In a separate iteration, rabbits were exposed to aerosolized B. anthracis Ames spores and lung samples were obtained through tissue sharing.

B. pseudomallei 1026b (26), F. tularensis Schu S4 (27), and Y. pestis CO92 (28) were grown until mid-log phase. Bacterial doses and the infection routes used were based on previous studies (Table 4) $(26,29-31)$. To minimize animal pain or distress, we administered meloxicam/ buprenorphine (32). Animals were observed at least twice daily, and when they were moribund, they were euthanized with pentobarbital (Vortech Pharmaceuticals, Ltd., http:// www.vortechpharm.com).

In compliance with the Animal Welfare Act, Public Health Service policy, and other federal statutes and regulations pertaining to animals and experiments involving animals, we conducted our research under an Institutional
Animal Care and Use Committee-approved protocol. The facility where this research was conducted is accredited by the Association for Assessment and Accreditation of Laboratory Animal Care, International and adheres to principles stated in the Guide for the Care and Use of Laboratory Animals, National Research Council, 2011 (https://www. aaalac.org; https:/grants.nih.gov/grants/olaw/guide-forthe-care-and-use-of-laboratory-animals.pdf).

\section{Inactivation Procedures and Viability Testing}

Skin injection sites from guinea pigs infected with Ames spores were incubated in fixative $(1: 10 \mathrm{wt} / \mathrm{vol})$ at ambient temperature. Lungs, livers, and spleens from euthanized or recently dead guinea pigs and rabbits were excised, divided into several pieces per tissue type, and submerged in fixative for various times. To remove excess fixative, we

Table 4. Routes of infection and delivered doses of Select Agents used to infect guinea pigs and rabbits for tissue collection in study of inactivation of bacterial Tier 1 Select Agents

\begin{tabular}{|c|c|c|c|c|c|}
\hline Bacteria & Route of infection & $\begin{array}{c}\text { Delivered dose, } \\
\text { CFU }\end{array}$ & Animal model & Time of collection & Tissue collected \\
\hline \multirow{3}{*}{$\begin{array}{l}\text { Bacillus anthracis Ames } \\
\text { (spores) }\end{array}$} & Intradermal & $2.7 \times 10^{8}$ & Guinea pigs-Hartley & $2 \mathrm{~h}$ after challenge & Skin \\
\hline & $\begin{array}{l}\text { Inhalational and/or } \\
\text { intramuscular, }\end{array}$ & $\begin{array}{l}4.9 \times 10^{6} \text { and } \\
1.0 \times 10^{3}\end{array}$ & Guinea pigs-Strain 13 & Late-stage disease & $\begin{array}{l}\text { Lung, liver, } \\
\text { spleen }\end{array}$ \\
\hline & Inhalational & $1.0 \times 10^{7}$ & $\begin{array}{c}\text { Rabbits-New Zealand } \\
\text { White }\end{array}$ & $24 \mathrm{~h}$ after challenge & Lung \\
\hline $\begin{array}{l}\text { Burkholderia pseudomallei } \\
1026 \mathrm{~b}\end{array}$ & Intraperitoneal & $9.0 \times 10^{2}$ & Guinea pigs-Strain 13 & Late-stage disease & $\begin{array}{l}\text { Lung, liver, } \\
\text { spleen }\end{array}$ \\
\hline Francisella tularensis Schu S4 & Subcutaneous & $8.6 \times 10^{2}$ & Guinea pigs-Strain 13 & Late-stage disease & $\begin{array}{l}\text { Lung, liver } \\
\text { spleen }\end{array}$ \\
\hline Yersina pestis CO92 & Subcutaneous & $7.0 \times 10^{4}$ & Guinea pigs-Strain 13 & Late-stage disease & $\begin{array}{l}\text { Lung, liver, } \\
\text { spleen }\end{array}$ \\
\hline
\end{tabular}


Table 5. Effect of residual formaldehyde in tissue from guinea pigs on the growth of Bacillus anthracis Sterne in study of inactivation of bacterial Tier I Select Agents*

\begin{tabular}{|c|c|c|c|c|}
\hline Tissue type, no. samples & Fixation time, $d$ & $\begin{array}{c}\text { Incubation time for tissue in } \\
\text { PBS/water }\end{array}$ & Sample inactivationt & $\begin{array}{c}\text { Positive control } \\
\text { inactivation } \dagger\end{array}$ \\
\hline Skin, 2 & 2 & $45 \min$ & $-1-$ & $+/+$ \\
\hline Skin, 2 & 14 & $45 \mathrm{~min}$ & $-1-$ & $+/+$ \\
\hline Skin, 2 & 21 & $45 \mathrm{~min}$ & $-1-$ & $+/+$ \\
\hline Ears, 2 & 2 & $45 \mathrm{~min}$ & $-1-$ & $+/+$ \\
\hline Ears, 2 & 14 & $45 \mathrm{~min}$ & $-1-$ & $-1-$ \\
\hline Ears, 2 & 21 & $45 \mathrm{~min}$ & $-1-$ & $-1-$ \\
\hline Spleen, 3 & 2 & $45 \mathrm{~min}$ & $-1-$ & $+/+$ \\
\hline Spleen, 3 & 17 & $45 \mathrm{~min}$ & $-1-$ & $-1-$ \\
\hline Spleen, 3 & 17 & $24 \mathrm{~h}$ & $-1-$ & $+/+$ \\
\hline Liver, 3 & 2 & $45 \mathrm{~min}$ & $-1-$ & $+/+$ \\
\hline Liver, 3 & 17 & $45 \mathrm{~min}$ & $-1-$ & $+/+\ddagger$ \\
\hline Liver, 3 & 17 & $24 \mathrm{~h}$ & $-1-$ & $+/+$ \\
\hline \multicolumn{5}{|c|}{$\begin{array}{l}\text { *Different fixation times }(2,14,17, \text { or } 21 \mathrm{~d}) \text { and wash times }(45 \mathrm{~min} \text { or } 24 \mathrm{~h}) \text { for skin, outer ear pinna, spleen, and liver result in the different ability of } \\
\text { Sterne spores to germinate and grow in broth used for viability testing. }+/- \text { indicates presence and/or absence of growth in broth/on plates; PBS, } \\
\text { phosphate-buffered saline. } \\
\text { †50\% of tissue tested. } \\
\ddagger \text { Of } 3 \text { samples, } 2 \text { were positive for growth and } 1 \text { was inhibited by residual formaldehyde. }\end{array}$} \\
\hline
\end{tabular}

soaked fixed tissues for $30 \mathrm{~min}$ and homogenized them. The entire homogenate volume was subjected to 7-day broth-to-plate viability testing, as previously described. To provide a positive control, we inoculated an additional sample with spores.

For B. pseudomallei $1026 \mathrm{~b}$, half of the homogenate was subjected to viability testing and the other half was reinoculated with live organism to serve as a positive control. Most tissue homogenates of Francisella and Yersinia were tested by using $10 \%$ of samples because of the necessary dilution in $10 \mathrm{~L}$ of broth for growth; however, spleen tissues with the highest bacterial load were further tested by using $90 \%$ of the samples in that volume $(10 \%$ was reinoculated for positive control). Burkholderia, Francisella, and Yersinia homogenates were incubated in broth and then incubated on solid medium at the appropriate temperature for 3-4 days each.

\section{Results}

Spores were able to germinate and grow in the presence of fixed skin or liver when the tissue was washed for a short time (45 min) (Table 5). In contrast, growth did not occur in ears or spleens fixed for a longer time (14-21 d) but washed for a short time. When washing was extended for a longer time $(24 \mathrm{~h})$, spleen tissue again permitted growth (Tables 5, 6), suggesting that the fixative was able to adequately diffuse out of the tissue with longer washing.
An alternative way to neutralize formaldehyde in fixed tissue is sufficient dilution in the broth used for viability testing. Thus, we determined the broth volume to which formaldehyde could be adequately diluted to permit growth of B. anthracis Sterne, B. pseudomallei 82, F. tularensis live vaccine strain, and $Y$. pestis Pgm-/pPst-. The growth of these non-Select Agents, used as surrogates, in broth containing $1 \%-0.001 \%$ formaldehyde, is shown in Table 7. Of note is the higher inoculum for $F$. tularensis live vaccine strain necessary to seed the broth cultures for growth. In contrast, substantially less inoculum was required for the other agents. B. pseudomallei 82 (a purine auxotroph) required longer incubation ( $5 \mathrm{~d}$ ) before a turbidity increase was evident. Therefore, we also performed the formaldehyde sensitivity assay with the virulent strain $1026 \mathrm{~b}$. These data indicate that formaldehyde can be washed out or adequately diluted in broth to permit a small number of live organisms, which may be present, to proliferate.

The skin is a difficult tissue for formaldehyde to infiltrate (16). Because of this property, along with the resistant nature of spores, to generate a time course of organism killing, we chose skin tissues infected with $B$. anthracis Ames spores. Spores in skin sections fixed for 14 or 21 days were completely inactivated (Table 1). In contrast, 7-day fixation was not adequate; growth occurred in 1 of 3 tissues. To maximize our dataset for inactivation of spore-containing

Table 6. Effect of residual electron microscopy fixative in tissue from guinea pigs on the growth of Bacillus anthracis Sterne in study of inactivation of bacterial Tier I Select Agents*

\begin{tabular}{lcccc}
\hline $\begin{array}{l}\text { Tissue type, no. } \\
\text { samples }\end{array}$ & Fixation time, d & $\begin{array}{c}\text { Incubation time for tissue in } \\
\text { PBS/water, h }\end{array}$ & Sample inactivationt & $\begin{array}{c}\text { Positive control } \\
\text { inactivationt }\end{array}$ \\
\hline Spleen, 3 & 14 & 24 & $-/-$ & $-/-$ \\
Spleen, 3 & & 24 & & $+/+$ \\
& 21 & & $-/-$ & $+/+$ \\
Liver, 3 & 14 & 24 & $-/-$ & $+/+$ \\
Liver, 3 & 21 & 24 & $+/+$ & +
\end{tabular}

*Spleen and liver tissues fixed for 14 or $21 \mathrm{~d}$ and washed for $24 \mathrm{~h}$ permitted Sterne spores to germinate and grow in broth used for viability testing. $+/-$ indicates presence and/or absence of growth in broth/on plates. PBS, phosphate-buffered saline.

$\uparrow 50 \%$ of tissue tested. 
Table 7. Growth of Bacillus, Burkholderia, Francisella, and Yersinia species in diluted formaldehyde in study of inactivation of bacterial Tier I Select Agents*

\begin{tabular}{|c|c|c|c|c|c|}
\hline Strain & CFU/volume & Growth condition & Time, $\mathrm{d}$ & NBF concentration, $\%$ & Growth \\
\hline Bacillus anthracis Sterne & 5 (bacilli)/500 mL & $\mathrm{BHI}, 37^{\circ} \mathrm{C}$ & 1 & $\begin{array}{c}0.1 \\
0.01 \\
0.001\end{array}$ & $\begin{array}{l}- \\
+ \\
+\end{array}$ \\
\hline Burkholderia pseudomallei 82 & $10 / 500 \mathrm{~mL}$ & $\mathrm{LB}+4 \%$ glycerol, $37^{\circ} \mathrm{C}$ & 5 & $\begin{array}{c}0.1 \\
0.01 \\
0.001\end{array}$ & $\begin{array}{l}- \\
- \\
+\end{array}$ \\
\hline B. pseudomallei 1026b & $5 / 500 \mathrm{~mL}$ & $\mathrm{LB}+4 \%$ glycerol, $37^{\circ} \mathrm{C}$ & 3 & $\begin{array}{c}0.1 \\
0.01 \\
0.001\end{array}$ & $\begin{array}{l}- \\
+ \\
+\end{array}$ \\
\hline Francisella tularensis LVS & $1.4 \times 10^{5} / 100 \mathrm{~mL}$ & $\mathrm{BHI}+1 \%$ IsoVitaleX, $37^{\circ} \mathrm{C}$ & 4 & $\begin{array}{c}0.1 \\
0.01 \\
0.001 \\
\end{array}$ & $\begin{array}{l}- \\
- \\
+\end{array}$ \\
\hline Yersina pestis $\mathrm{Pgm}^{-} / \mathrm{pPst}^{-}$ & $10 / 100 \mathrm{~mL}$ & $\mathrm{HI}+0.2 \%$ xylose, $28^{\circ} \mathrm{C}$ & 3 & $\begin{array}{c}0.1 \\
0.01 \\
0.001 \\
\end{array}$ & $\begin{array}{l}- \\
- \\
+\end{array}$ \\
\hline
\end{tabular}

tissues, we also fixed lung tissues from rabbits infected with $B$. anthracis Ames spores. Of 3 lung samples, 2 were inactivated at 13 days and the third was inactivated at 20 days (Table 8).

The tissues that we commonly collect and fix for histopathologic analysis are spleen, liver, and lung. Organisms in all infected spleen, liver, and lung samples fixed for various times were inactivated (Table 2). Specifically, we found complete inactivation in spleens infected with the highest load of B. anthracis Ames, F. tularensis Schu S4, or $Y$. pestis CO92, tested by using either $90 \%$ or $100 \%$ of the samples. This inactivation includes $B$. anthracis Amesinfected lung tissue from guinea pigs, which also contained heat-resistant spores. Also completely inactivated were $B$. pseudomallei $1026 \mathrm{~b}$-infected spleen and other tissues, tested by using $50 \%$ of the samples. Similar to formaldehydefixed tissues, tissues incubated in EM fixative were also inactivated (Table 3).

\section{Discussion}

We examined the effectiveness of formaldehyde, by itself and with glutaraldehyde, to inactivate tissues infected with Select Agents. We found that 14 days in formaldehyde and 7 days in EM fixative are generally sufficient to completely inactivate most infected tissues described in this report, including tissues containing high numbers of resistant spores and hard-to-infiltrate tissues like skin. One exception was a rabbit lung in which B. anthracis spores were only partially inactivated at 13 days of fixation but inactivated at 20 days. Although we show that inactivation can probably be achieved in less time, to ensure an adequate safety margin, no change in our institutional standard operating procedure of 21 days fixation will be made.

At the study's inception, we experimented with injecting Select Agents into tissues collected from euthanized animals. However, this ex vivo approach failed because the tissues did not retain the inoculum. Of note, this attempt did not recapitulate in vivo diseased tissue, where organisms are probably distributed more homogeneously. Although we were fortunate to obtain rabbit lung tissues from an ongoing study, other already infected tissues were not readily available. Thus, we infected animals specifically for this work. In addition to infecting with the Select Agents we commonly work with, we also validated different tissue types such as skin and lung, tissues in which a substantial amount of ungerminated spores would remain after exposure. We specifically examined the number of ungerminated spores in rabbit and guinea pig tissues because the chemical sensitivities of spores and bacilli differ greatly.

For this study, we used tissues $\leq 10 \mathrm{~mm}$ thick in 1 dimension. Although it is possible to excise and fix tissue

Table 8. Formaldehyde fixation of infected lung tissue from rabbits exposed to aerosolized Bacillus anthracis Ames spores in study of inactivation of bacterial Tier I Select Agents*

\begin{tabular}{|c|c|c|c|c|c|c|c|}
\hline \multirow[b]{2}{*}{ Rabbit no. } & \multirow[b]{2}{*}{ Tissue weight, $\mathrm{g}$} & \multirow[b]{2}{*}{ Tissue size, mm } & \multirow{2}{*}{$\begin{array}{l}\text { Total CFU } \\
\text { recovered/g }\end{array}$} & \multirow{2}{*}{$\begin{array}{c}\text { Heat-resistant CFU } \\
\text { recovered/g }\end{array}$} & \multicolumn{2}{|c|}{ Time of inactivation } & \multirow{2}{*}{$\begin{array}{l}\text { Positive } \\
\text { control }\end{array}$} \\
\hline & & & & & $13 \mathrm{~d}$ & $20 \mathrm{~d}$ & \\
\hline 1 & 0.72 & $10 \times 10 \times 10$ & $1.2 \times 10^{7}$ & $1.5 \times 10^{6}$ & $-1-\dagger$ & ND & $+/+$ \\
\hline 2 & 0.74 & $10 \times 10 \times 10$ & $4.4 \times 10^{5}$ & $4.3 \times 10^{5}$ & $-1-+$ & ND & $+/+$ \\
\hline 3 & $0.71 / 0.75$ & $10 \times 10 \times 10$ & $2.6 \times 10^{6}$ & $1.0 \times 10^{6}$ & $+/++$ & $-1-+$ & $+/+$ \\
\hline
\end{tabular}

*Infected lung tissues from 3 rabbits were fixed for 13 or $20 \mathrm{~d}$ in $4 \%$ paraformaldehyde, rinsed for 30 min in phosphate-buffered saline, and then homogenized. Listed are the tissue weight, size, and CFU recovered. +/- indicates presence and/or absence of growth in broth/on plate. ND, not done. $\uparrow 50 \%$ of sample tested. 
$>10 \mathrm{~mm}$ thick, this practice is discouraged because it hampers fixative infiltration into the deep recesses of the tissue; these areas probably also undergo putrefaction before becoming fixed (10). Infiltration is already slowed in tissues such as skin and fat $(16,17)$, so exceeding the limit set forth here $(10 \mathrm{~mm})$ will probably lengthen the time needed to inactivate. Exceeding the organ bacterial burdens greater than those stated (Tables 2,3) would also require reevaluation (23) because these could require more time to inactivate. Other institutions may use this work as a guide to conduct and develop their own testing to comply with the policy. Furthermore, these methods may be useful in the processing and inactivation of tissues from patients infected with Select Agents for diagnostic testing by state public health laboratories and CDC.

This work was funded by the US Department of Defense.

\section{About the Author}

Dr. Chua is a microbiologist/cell biologist who specializes in microscopy. Her research interest includes infectious diseases and microbial pathogenesis.

\section{References}

1. Bozue JA, Cote CK, Glass PJ, editors. Medical aspects of biological warfare. Fort Sam Houston (TX): Borden Institute, Office of the Surgeon General of the United States Army; 2018.

2. US Department of Defense. Inadvertent shipment of live. Bacillus anthracis spores by DoD: 2015 July 13 [cited 2019 Jan 13]. www.defense.gov/Portals/1/features/2015/0615 lab-stats/ Review-Committee-Report-Final.pdf

3. Cote CK, Buhr T, Bernhards CB, Bohmke MD, Calm AM, Esteban-Trexler JS, et al. A standard method to inactivate Bacillus anthracis spores to sterility using gamma-irradiation. Appl Environ Microbiol. 2018;84:AEM.00106-18. http://dx.doi.org/10.1128/ AEM.00106-18

4. Centers for Disease Control and Prevention, Department of Health and Human Services. Possession, use and transfer of select agents and toxins; biennial review of the list of select agents and toxins and enhanced biosafety requirements. Final rule. Fed Regist. 2017; 82:6278-94.

5. Blum F. Der Formaldehyd als Antisepticum. Münchener medicinische Wochenschrift. 1893;32:601-2.

6. Sabatini DD, Bensch K, Barrnett RJ. Cytochemistry and electron microscopy. The preservation of cellular ultrastructure and enzymatic activity by aldehyde fixation. J Cell Biol. 1963;17:1958. http://dx.doi.org/10.1083/jcb.17.1.19

7. Fox CH, Johnson FB, Whiting J, Roller PP. Formaldehyde fixation. J Histochem Cytochem. 1985;33:845-53. http://dx.doi.org/ $10.1177 / 33.8 .3894502$

8. Jones D. Reactions of aldehydes with unsaturated fatty acids during histological fixation. Histochem J. 1972;4:421-65. http://dx.doi.org/10.1007/BF01012533

9. Kunkel GR, Mehrabian M, Martinson HG. Contact-site cross-linking agents. Mol Cell Biochem. 1981;34:3-13. http://dx.doi.org/10.1007/BF02354846

10. Thavarajah R, Mudimbaimannar VK, Elizabeth J, Rao UK, Ranganathan K. Chemical and physical basics of routine formaldehyde fixation. J Oral Maxillofac Pathol. 2012;16:400-5. http://dx.doi.org/10.4103/0973-029X.102496
11. Sompuram SR, Vani K, Messana E, Bogen SA. A molecular mechanism of formalin fixation and antigen retrieval. Am J Clin Pathol. 2004;121:190-9. http://dx.doi.org/10.1309/ BRN7CTX1E84NWWPL

12. Phillips GB, Novak F, Hanel E Jr. Germicidal effectiveness of formaldehyde fixatives and preservatives against Bacillus anthracis in animal tissue. Am J Med Technol. 1955;21:89-91.

13. Malinina ZE, Isupov IV, Dudkova VK. Bactericidal action of formalin on the causative agent of plague [in Russian]. Arkh Patol. 1979;41:80-2.

14. Brantner CA, Hannah RM, Burans JP, Pope RK. Inactivation and ultrastructure analysis of Bacillus spp. and Clostridium perfringens spores. Microsc Microanal. 2014;20:238-44. http://dx.doi.org/10.1017/S1431927613013949

15. Chafin D, Theiss A, Roberts E, Borlee G, Otter M, Baird GS. Rapid two-temperature formalin fixation. PLoS One. 2013;8:e54138. http://dx.doi.org/10.1371/journal.pone.0054138

16. Buesa RJ, Peshkov MV. How much formalin is enough to fix tissues? Ann Diagn Pathol. 2012;16:202-9. http://dx.doi.org/10.1016/j.anndiagpath.2011.12.003

17. Bauer DR, Stevens B, Chafin D, Theiss AP, Otter M. Active monitoring of formaldehyde diffusion into histological tissues with digital acoustic interferometry. J Med Imaging (Bellingham). 2016;3:017002. http://dx.doi.org/10.1117/1.JMI.3.1.017002

18. Setlow P. Spores of Bacillus subtilis: their resistance to and killing by radiation, heat and chemicals. J Appl Microbiol. 2006;101:51425. http://dx.doi.org/10.1111/j.1365-2672.2005.02736.x

19. Leighton TJ, Doi RH. The stability of messenger ribonucleic acid during sporulation in Bacillus subtilis. J Biol Chem. 1971;246:3189-95.

20. Green BD, Battisti L, Koehler TM, Thorne CB, Ivins BE. Demonstration of a capsule plasmid in Bacillus anthracis. Infect Immun. 1985;49:291-7.

21. Cote CK, Van Rooijen N, Welkos SL. Roles of macrophages and neutrophils in the early host response to Bacillus anthracis spores in a mouse model of infection. Infect Immun. 2006;74:469-80. http://dx.doi.org/10.1128/IAI.74.1.469-480.2006

22. Chua J, Fisher NA, Falcinelli SD, DeShazer D, Friedlander AM. The Madagascar hissing cockroach as an alternative nonmammalian animal model to investigate virulence, pathogenesis, and drug efficacy. J Vis Exp. 2017;129:e56491. PMID: 29286449

23. Centers for Disease Control and Prevention. Revised FSAP policy statement: inactivated Bacillus anthracis and Bacillus cereus biovar anthracis. 2017 August 14 [cited 2019 Jan 13]. http://www.selectagents.gov/policystatement_bacillus.html

24. Hartings JM, Roy CJ. The automated bioaerosol exposure system: preclinical platform development and a respiratory dosimetry application with nonhuman primates. J Pharmacol Toxicol Methods. 2004;49:39-55. http://dx.doi.org/10.1016/ j.vasen.2003.07.001

25. Bozue JA, Parthasarathy N, Phillips LR, Cote CK, Fellows PF, Mendelson I, et al. Construction of a rhamnose mutation in Bacillus anthracis affects adherence to macrophages but not virulence in guinea pigs. Microb Pathog. 2005;38:1-12. http://dx.doi.org/10.1016/j.micpath.2004.10.001

26. DeShazer D, Brett PJ, Woods DE. The type II O-antigenic polysaccharide moiety of Burkholderia pseudomallei lipopolysaccharide is required for serum resistance and virulence. Mol Microbiol. 1998;30:1081-100. http://dx.doi.org/10.1046/ j.1365-2958.1998.01139.x

27. Chance T, Chua J, Toothman RG, Ladner JT, Nuss JE, Raymond JL, et al. A spontaneous mutation in $k d s D$, a biosynthesis gene for 3 deoxy-D-manno-octulosonic acid, occurred in a ciprofloxacin resistant strain of Francisella tularensis and caused a high level of attenuation in murine models of tularemia. PLoS One. 2017;12:e0174106. http://dx.doi.org/10.1371/journal.pone.0174106 
28. Bozue J, Cote CK, Chance T, Kugelman J, Kern SJ, Kijek TK, et al. A Yersinia pestis tat mutant is attenuated in bubonic and small-aerosol pneumonic challenge models of infection but not as attenuated by intranasal challenge. PLoS One. 2014;9:e104524. http://dx.doi.org/10.1371/journal.pone.0104524

29. Hood AM. Virulence factors of Francisella tularensis. J Hyg (Lond). 1977;79:47-60. http://dx.doi.org/10.1017/ S0022172400052840

30. Samoilova SV, Samoilova LV, Yezhov IN, Drozdov IG, Anisimov AP. Virulence of pPst+ and pPst- strains of Yersinia pestis for guinea-pigs. J Med Microbiol. 1996;45:440-4. http://dx.doi.org/10.1099/00222615-45-6-440
31. Jenkins A, Cote C, Twenhafel N, Merkel T, Bozue J, Welkos S. Role of purine biosynthesis in Bacillus anthracis pathogenesis and virulence. Infect Immun. 2011;79:153-66. http://dx.doi.org/ 10.1128/IAI.00925-10

32. Stevens KA, Wilson RP, Suckow MA, editors. The Laboratory Rabbit, Guinea Pig, Hamster, and other Rodents. 1st ed. Boston: Academic Press (Elsevier); 2012.

Address for correspondence: Jennifer Chua or Christopher K. Cote, USAMRIID, 1425 Porter St, Frederick, MD 21702, USA; email: jennifer.chua.ctr@mail.mil or christopher.k.cote.civ@mail.mil

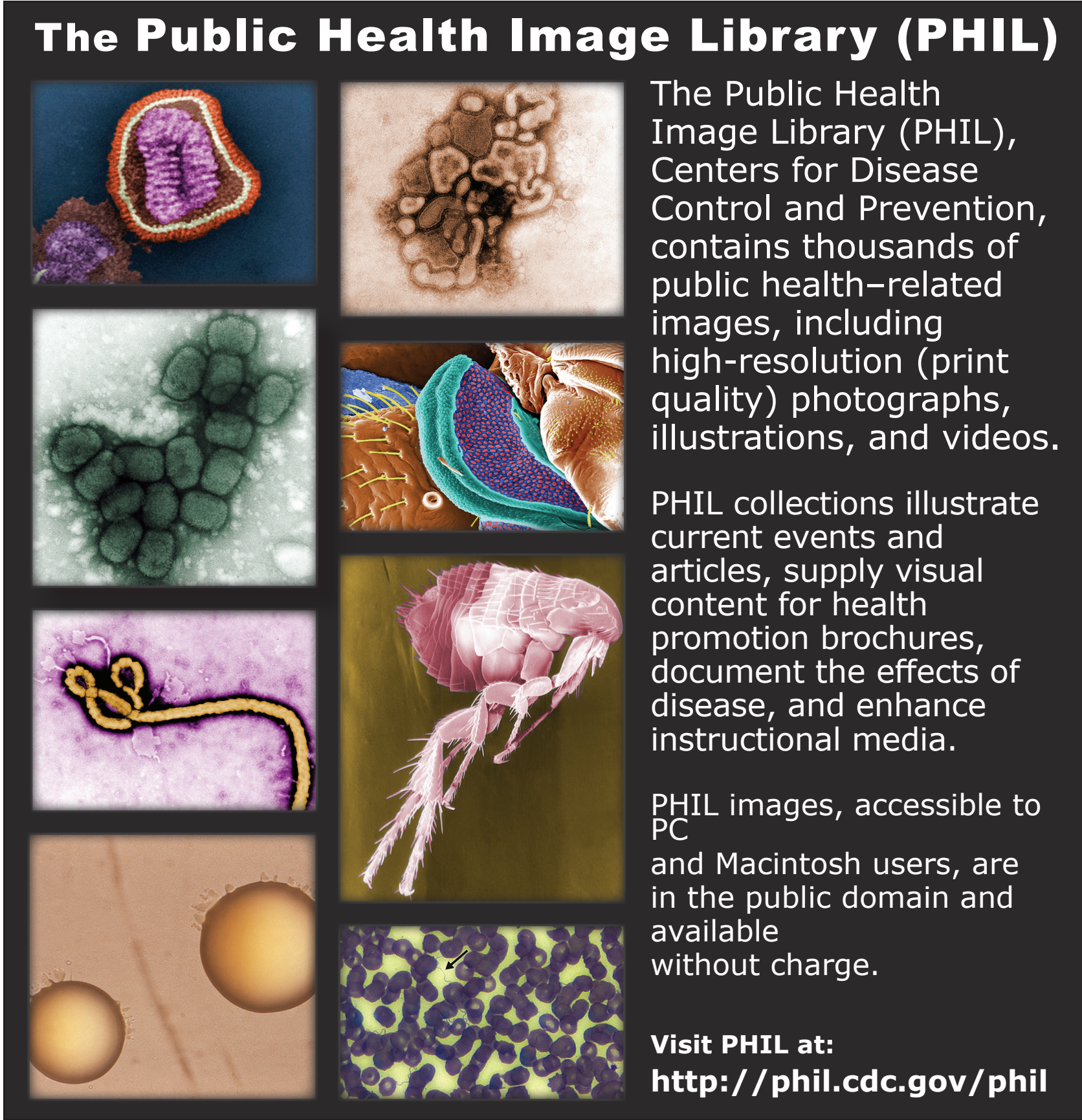

